\title{
Discussion points on the early days of crowdfunding research in
}

\author{
Vietnam \\ Ho Manh Tung \\ Ritsumeikan Asia Pacific University \\ Верри, Oita, Japan
}

February 11, 2021

There are very few studies related to crowdfunding research. The indexed ones are even fewer. According to the SSHPA database [1], the most updated and high-quality database that tracks international publications of Vietnamese social scientists since 2008, there are only two papers $[2,3]$, that are tangentially related to crowdfunding. Looking beyond this database, there is one master thesis [4] and a paper from the Asian Institute of Research [5]. All studies only focus on the performance of the founders or the banks, thus, the depth of this area of research has not been dealt with properly in these studies. One of the most important aspects that is being overlooked is the role of Vietnamese business culture on the level of receptiveness with this newly emerging concept of crowdfunding.

With crowdfunding being a new concept in Vietnamese society, there is a need for explaining how Vietnamese people receive this new way of investing. Fortunately, we have the mindsponge mechanism to do this job [6,7]. For example, crowdfunding is translated to Vietnamese in the mass media as "gọi vốn cộng đồng," which inadvertently emphasizes the community aspect. This leads to, I suspect, many potential investors equate this term with charity projects such as the one by the singer Thuy Tien. However, crowdfunding has many forms: equity- 
based, lending-based, or royalty-based, which are essentially about investing. A mindset shift, hence, is needed to make this form of investing prevalent and attractive to many people.

Here, it is important to state that Vietnam has always been a society imbued with the entrepreneurial spirit $[8,9,10]$, even well before the instalment of the Doi Moi policy in 1986 [11]. Thus, it would be insufficient when a study only uses regression analysis to find correlations between a set of firms/founders' traits with the success of a crowdfunding project [12]. The very definition of success can change when there is cultural change. And culture could also vary from one organization to another. Thus, to rigorously study the new phenomenon of crowdfunding, one must ground future studies of crowdfunding in Vietnam in suitable literature and suitable conceptual framework. Here I believe there are two concepts that are up to task. The first is mindsponge model that explains an individual's shift in mindset. And the second is the cultural additivity theory that explains how new values are added or subtracted in a cultural setting $[13,14$, $16]$.

\section{References}

1. Vuong, Q.-H., La, V.-P., Vuong, T.-T., Ho, M.-T., Nguyen, H.-K. T., Nguyen, V.-H., Pham, H.-H., \& Ho, M.-T. (2018). An open database of productivity in Vietnam's social sciences and humanities for public use. Scientific Data, 5(1), 180188. https://doi.org/10.1038/sdata.2018.188

2. Nguyen, M.-H., Pham, T.-H., Ho, M.-T., Nguyen, H. T. T., \& Vuong, Q.-H. (2020). On the social and conceptual structure of the 50-year research landscape in entrepreneurial finance. SN Business \& Economics, 1(1), 2. https://doi.org/10.1007/s43546-020-00002-z 
3. Phan, D. H. B., Narayan, P. K., Rahman, R. E., \& Hutabarat, A. R. (2020). Do financial technology firms influence bank performance? Pacific-Basin Finance Journal, 62, 101210. https://doi.org/https://doi.org/10.1016/j.pacfin.2019.101210

4. Nguyen, T. (2017). Crowdfunding in Vietnam: The impact of project and founder quality on funding success. [Master thesis, University of Twente]. Retrieved 2021, January 29 from http://essay.utwente.nl/73270/

5. Linh, D. (2019). Impacts of founder on the success of crowdfunding in Vietnam. Journal of Economics and Business, 2(2), 356-362. https://doi.org/10.31014/aior.1992.02.02.92

6. Vuong, Q. H. (2016). Global mindset as the integration of emerging socio-cultural values through mindsponge processes: A transition economy perspective. In J. Kuada (Ed.), Global Mindsets: Exploration and Perspectives (pp. 109-126). Routledge.

7. Vuong, Q. H., \& Napier, N. K. (2014). Making creativity: The value of multiple filters in the innovation process. International Journal of Transitions and Innovation Systems, 3(4), 294-327.

8. Vuong, Q.-H. (2019). Breaking barriers in publishing demands a proactive attitude. Nature Human Behaviour, 3(10), 1034-1034. https://doi.org/10.1038/s41562-019-0667-6

9. Vuong, Q.-H., La, V.-P., Vuong, T.-T., Nguyen, H.-K. T., Ho, M.-T., \& Ho, M.-T. (2020). What have Vietnamese scholars learned from researching entrepreneurship? A Systematic review. Heliyon, 6(4). https://doi.org/10.1016/j.heliyon.2020.e03808

10. Vuong, Q.-H. \& Tran, T. D. (2009). The cultural dimensions of the Vietnamese private entrepreneurship. IUP Journal of Entrepreneurship Development, VI(3-4): 54-78. 
11. Chính, P. M., \& Hoàng, V. Q. (2009). Kinh tế Việt Nam: Thăng trầm và đột phá. Nxb Chính trị Quốc gia, Hà Nội.

12. Vuong, Q. H., Ho, T. M., \& La, V. P. (2019). 'Stargazing' and p-hacking behaviours in social sciences: some insights from a developing country. European Science Editing, 45(2), 5657.

13. Vuong, Q.-H., Bui, Q.-K., La, V.-P., Vuong, T.-T., Nguyen, V.-H. T., Ho, M.-T., Nguyen, H.K. T., \& Ho, M.-T. (2018). Cultural additivity: behavioural insights from the interaction of Confucianism, Buddhism and Taoism in folktales. Palgrave Communications, 4(1), 143. https://doi.org/10.1057/s41599-018-0189-2

14. Vuong, Q.-H., Ho, M.-T., Nguyen, H.-K. T., Vuong, T.-T., Tran, T., Hoang, K.-L., Vu, T.-H., Hoang, P.-H., Nguyen, M.-H., Ho, M.-T., \& La, V.-P. (2020). On how religions could accidentally incite lies and violence: folktales as a cultural transmitter. Palgrave Communications, 6(1), 82. https://doi.org/10.1057/s41599-020-0442-3

15. Vuong, Q.-H., Bui, Q.-K., La, V.-P., Vuong, T.-T., Ho, M.-T., Nguyen, H.-K. T., Nguyen, H.N., Nghiem, K.-C. P., \& Ho, M.-T. (2019). Cultural evolution in Vietnam's early 20th century: A Bayesian networks analysis of Hanoi Franco-Chinese house designs. Social Sciences \& Humanities $\quad$ Open, $1(1), \quad 100001$. https://doi.org/https://doi.org/10.1016/j.ssaho.2019.100001

16. La VP, Vuong QH. (2019). bayesvl: Visually Learning the Graphical Structure of Bayesian Networks and Performing MCMC with 'Stan'. The Comprehensive R Archive Network $(C R A N): \quad<$ https://cran.r-project.org/web/packages/bayesvl/index.html > $;$ version 0.8 .5 (officialy published on May 24, 2019). 
